\title{
THE EFFECT OF AGING ON ELEMENT PLANT AVAILABILITY AND BACTERIAL COUNTS OF MIXTURES OF WOOD ASH AND SEWAGE SLUDGE
}

\author{
Yudani Pousada-Ferradás ${ }^{1}$, Socorro Seoane-Labandeira ${ }^{1}$, Miguel Blanco ${ }^{2}$, \\ Avelino Núñez-Delgado ${ }^{1}$
}

\begin{abstract}
This study investigated the chemical composition of a mixture of $70 \%$ wood ashes (a by-product of timber-industry) and 30\% sewage sludge (\% dry weight), immediately after preparation and after storage (42 days). The mixture had higher Mehlich 3 extractable $\mathrm{Ca}, \mathrm{Mg}$ and $\mathrm{K}$ concentrations than either component alone, and low plant-available heavy metal concentrations, both immediately after mixing and after storage for up to 6 weeks. The results support the view that mixtures of this type may be useful for liming and fertilizing, given their neutralizing capacity and phyto nutrient concentrations. Furthermore, we compared the survival of Escherichia coli in a wood ash and sewage sludge mixture with their survival in mixtures of sewage sludge and two levels of quicklime. The time needed to eliminate most bacteria was 29 days in the ash-sludge combination, while nine days were required for one of the quicklime-sludge mixtures, and counts were minimal for the quicklime-sludge mixture with a $\mathrm{pH}>12$.
\end{abstract}

Keywords: Wood ash, sewage sludge, quicklime, mixtures, E. coli counts

\section{INTRODUCTION}

Wood ash is produced in large quantities by timber-industry factories which burn waste biomass as fuel for energy production. The storage or disposal of this ash generates significant costs. The total annual generation of ash from biofuels in Sweden is estimated as 250.000-300.000 tonnes (Mellbo et al. 2008), and in Galicia (northwest Spain) a figure of $40.000-50.000$ tonnes per annum has been suggested (Sueiro 2010). In general, timber-industry wood ash is stored on land specifically allocated for this use, or is dumped on general waste tips; however, a small proportion is used as a construction material, or for agricultural liming and fertilization. The characteristics of wood ash are highly variable (Misra et al. 1993, Demeyer et al. 2001, Augusto et al. 2008). However, the main components of wood ash are generally calcium, potassium and magnesium (Demeyer et al. 2001, Vance 1996). Sulphur, phosphorus and manganese are typically present at about $1 \% \mathrm{w} / \mathrm{w}$, with iron, aluminium, copper, zinc, sodium, silicon and boron also present at lower concentrations. Combustion is often incomplete, so that carbon concentration is usually high. Nitrogen is present at very low concentrations, since it is volatilized during combustion. Neutralizing capacity is generally about $25-50 \%$ of that of calcium carbonate (Sumner, 2000). The addition of wood ash to acid soils generally has positive effects, since it increases $\mathrm{pH}$, reduces exchangeable $\mathrm{Al}$, increases exchangeable $\mathrm{Ca}$ and $\mathrm{Mg}$, and increases cation exchange capacity (Van Hees et al. 2003). However, the use of wood ash for soil amendment over long periods may lead to excessive build-up of sulphates, nitrates or soluble organic carbon (Lundström et al. 2003), or of low-molecular-weight organic compounds (Holmström et al. 2003). Furthermore, wood ashes can contain high heavy metal concentrations, and organic pollutants, and thus spreading wood ashes in a forest would be a major anthropogenic interference with the natural biogeochemical

\footnotetext{
'Departamento Edafología y Química Agrícola, Universidad Santiago de Compostela. Escuela Politécnica Superior, Campus Univ. s/n, 27002 Lugo. Spain

${ }^{2}$ Laboratorio de Referencia de E. coli, Departamento Microbiología y Parasitología, Universidad Santiago de Compostela Facultad Veterinaria,

Campus Univ. s/n, 27002 Lugo. Spain.

Corresponding author: avelino.nunez@usc.es

Received: 14.01.2011 Accepted.31.07.2011
} 
cycles (Reimann et al. 2008). Augusto et al. (2008) indicate that wood ash may contain high amounts of heavy metals, but no contamination of food chains has been reported, and heavy metals remain in the forest litter or in the topsoil. Saarsalmi et al. (2006) have found increased heavy metals concentrations in the humus layer after wood ash spreading, but, as regards $\mathrm{Cd}$, these authors indicate that elevated $\mathrm{Cd}$ concentrations found in several studies in Finland have in all cases been within the normal variation range of Cd concentrations in Finnish soils in background areas.

The amount of waste produced in the world continues to increase, and there is a need for management strategies beyond simple dumping, storage or incineration. In some cases, the physical and chemical characteristics of the waste offers potential for some sort of productive re-use or recycling (Sumner 2000). This is the case with both timber-industry wood ashes and sewage sludge.

Sewage sludge production is increasing. The chemical and microbiological composition of wastewater treatment plants (WTP) sludge depends on the type of effluent entering the plant, on effluent treatment processes, and on subsequent sludge treatment processes. This sludge typically has high organic matter concentration, variable amounts of nitrogen, phosphorus and potassium, and in some cases high concentrations of metals, notably zinc, chromium, copper and/or lead (Canet et al. 1998).

Well-designed mixtures of waste products may offer more balanced nutrient concentrations and better handling properties than either product individually (Sumner 2000, Pousada et al. 2005a, 2005b, Holmberg et al. 2000). Several authors have evaluated the use of mixtures of coal ash and diverse biosolids as agricultural amendments (Jackson et al. 1999, Schumann and Sumner 2000, Abbott et al. 2001), with results indicating that interesting nutrient combinations can be obtained in this way. Authors as Dimitriou et al. (2006) have tried sewage sludge and wood ash mixtures finding no heavy metal pollution in short rotation willow coppice. Mixtures of wood ash and WTP sludge can be expected to show better physical properties as regards handling, and a more balanced phyto nutrient composition, than either component individually. This thus seems an option for the disposal/re-use of these wastes. In preliminary studies we found that mixtures with $70 \%$ ash and $30 \%$ sludge were optimal in terms of ease of handling and application. These proportions are similar to those tested by Dimitriou et al. (2006), and others (Jackson et al. 1999, Schumann and Sumner 2000) in studies of mixtures of coal ash and bio-solids. Various considerations suggest that a certain minimal storage period would be required for physical and chemical stabilization of these mixtures; and conversely, it is important to know how long these mixtures can be stored without losing their beneficial properties, or even its time-course evolution in storage conditions.

In the present study we performed a physical and chemical characterization of a $70 \% / 30 \%$ mixture of wood ash and sewage sludge, and evaluated changes in physical and chemical properties over storage for up to 6 weeks. Furthermore, we compared the survival of Escherichia coli in another batch of $70 \% / 30 \%$ wood-ash/sewage-sludge mixture with their survival in two quicklime and sewage sludge mixtures after $0,9,14$ and 29 days of storage.

\section{MATERIAL AND METHODS}

\section{Material collection}

The ashes were from the timber factory of Tablicia (Lugo, Spain). Ashes were derived from the combustion of pine bark and woody untreated residues from P. radiata $(70 \%)$ and Pinus pinaster $(30 \%)$, bark being the principal component (65\%) burned in the plants (Solla-Gullón et al. 2008). The ashes were collected from the base of the furnace, and thus did not include the lightest fly-ash fractions, which were removed by aspiration, according to normal factory practice. After multiple random subsampling, a single sample ( $75 \mathrm{Kg}$, wet weight) was obtained and homogenized (without pulverization) to increase representativity. 
The sludge analysed was from the Lugo WTP (Lugo, Spain), where it was randomly sampled, and multiple subsamples were combined to create a single composite sample.At the WTP, the primary sludge (from physico-chemical treatment) and the secondary sludge (from biological treatment) are mixed after being thickened in an intermediate tank before being fed into the anaerobic digester; afterwards, they are dewatered in a belt filter (Hospido et al. 2007). The sludge sample (totalling $47 \mathrm{~kg}$, wet weight) was transported to the laboratory in a hermetically sealed polyethylene bag.

\section{Mixtures}

The first and second ash-sludge mixtures(A-S-1 and A-S-2, $10 \mathrm{~kg}$ of each one) were prepared according to the protocol of Pousada et al. (2003), with 70\% d.w. ash and 30\% d.w. sludge. Briefly: the sludge and ash were mixed together, varying the proportions until obtaining suitable results in terms of consistency (formation of aggregates), odour and $\mathrm{pH}$ of the final product. The first mixture (A-S-1), used to study aging effects, was placed in twelve $500-\mathrm{cm}^{3}$ polyethylene tubs, which were covered with filter paper "lids" to prevent entry of airborne solids, but allowing gas transfer. These were then maintained at ambient temperature $\left(20^{\circ} \mathrm{C}\right)$ in the laboratory for up to 6 weeks.

The ash, the sludge, and the A-S- 1 ash-sludge mixture were characterized at $0,1,3$, and 6 weeks. Three tubs of sample were used for each aging period and all analyses were performedin quadruplicate.

Another batch was prepared with a new 70\% $+30 \%$ ash-sludge mixture(A-S-2) and with two mixtures of quicklime from CEDIESA (Barco de Valdeorras, Spain) and sludge, prepared at percentages of 15\%+ $85 \%$ (Q-S-1) and $41 \%+59 \%$ (Q-S-2), giving $10 \mathrm{~kg}$ of each mixture. In this case, sterilized laboratory material was used in order to carry out microbiological tests, comparing the survival of $E$. coli in the ash-sludge mixture with survival in two sewage sludge-quicklime mixtures after $0,9,14$ and 29 days of storage.

\section{Physical and chemical properties}

Note that the $>4 \mathrm{~mm}$ fraction (that includes coarse gravel) was removed before analysis. Moisture content was determined on the basis of weight loss at $105^{\circ} \mathrm{C}$. Electrical conductivity (EC) and pH were determined by electrometric methods. Carbon concentration was determined by oxidation with potassium dichromate (Guitián and Carballas 1976), and nitrogen by the Kjeldahl method (Tan 1996). The oxidation method for $\mathrm{C}$ determination may cause some uncertainty, mainly when used in ash samples, although it is highly employed for soils, where ash, sludge or ash-sludge mixtures will be finally spread, Phosphorus was determined by colorimetry with ascorbic acid (Tan 1996), both in aqueous extracts and in the extract obtained with Mehlich 3 reagent (Mehlich 1984). Metals (Ca, Mg, Na, K, Fe, Al, Mn, Zn, Ni, Cu, Co, $\mathrm{Cd}, \mathrm{Cr}, \mathrm{Pb}, \mathrm{Mo}$, and $\mathrm{Hg}$ ), also $\mathrm{As}, \mathrm{B}$ and $\mathrm{S}$, were likewise determined both in aqueous extracts and in Mehlich 3 extracts, by inductively coupled plasma optical emission spectroscopy (ICP-OES), or coldvapour-mercury atomic absorption spectrophotometry for $\mathrm{Hg}$.

\section{E. coli Most Probable Number (E. coli-MPN)}

The most probable number of E. coli was determined using a commercial system (Petrifilm ${ }^{\mathrm{TM}}$ Select E. coli, 3M, St. Paul, MN, USA) according to manufacture's indications. This system is based on the enzymatic activity of beta-glucuronidase (GUD), produced by approximately $97 \%$ of $E$. coli strains, which reacts with an indicator dyein the Petrifilm plate which makes the colony turn from dark green to blue-green. Briefly, a 1:10 dilution was aseptically prepared with 25 grams of each sample added to 250 $\mathrm{cm}^{3}$ of buffered peptone water (ISO 6887). The diluted samples were homogenised in a homogenizer, and $1 \mathrm{~cm}^{3}$ of sample was placed perpendicularly onto the centre of a Petrifilm. The Petrifilms were incubated at $44^{\circ} \mathrm{C} 24$ hours. Dark green to blue-green colonies were counted for each sample. Representative colonies from each sample were picked to confirm them as E. coli by standard biochemical procedures (glucose positive, $\mathrm{SH}_{2}$ negative, citrate negative, urease positive, and indol positive). 


\section{Characteristics of the ashes}

\section{RESULTS AND DISCUSSION}

The ashes were collected from the bottom of the furnace, so that particle size was coarse: about $70 \%$ of dry weight had particle size $>2 \mathrm{~mm}$, and about $58 \%$ had particle size $>4 \mathrm{~mm}$ (Table 1).Chemical properties of the ashes are summarized in table 2. As expected, it is an alkaline material with low $\mathrm{N}$ concentration and high $\mathrm{C} / \mathrm{N}$ ratio. High variability has been found for these ashes after several years of sampling and analysis, but it seems clear that it could be improved for being used as soil amendment if it would be mixed with an appropriate material with higher $\mathrm{N}$ content.

Table 1. Particle size distribution of the first wood ash batch used in the present study (percentage of dry weight).

\begin{tabular}{|cc|}
\hline Fraction & \% dry weight \\
\hline$>4 \mathrm{~mm}$ & 57.8 \\
$4-2 \mathrm{~mm}$ & 12.3 \\
$2-0.5 \mathrm{~mm}$ & 15.0 \\
$<0.5 \mathrm{~mm}$ & 14.9 \\
\hline
\end{tabular}

Table 2. Physical and chemical properties of the first wood ash and sewage sludge batch used in the present study

\begin{tabular}{|lll|}
\hline & Ash & Sludge \\
\hline Moisture content $(\%)$ & 38.0 & 83.4 \\
$\mathrm{pH}\left(\right.$ in $\left.\mathrm{H}_{2} \mathrm{O}\right)$ & 8.82 & 7.98 \\
$\mathrm{EC}\left(\mu \mathrm{S} \mathrm{cm}^{-1}\right)$ & 123.5 & 1423 \\
Carbon $\left(\mathrm{g} \mathrm{kg}^{-1}\right.$ dry weight $)$ & 280 & 60.4 \\
Total Kjeldahl N $\left(\mathrm{g} \mathrm{kg}^{-1}\right.$ dry weight $)$ & 1.0 & 2.6 \\
$\mathrm{C} / \mathrm{N}$ ratio & 280 & 23 \\
\hline
\end{tabular}

Water-soluble and Mehlich-3-extractable calcium, magnesium and potassium concentrations were all high, as was soluble sodium concentration (Table 3). However, concentrations of these metals were consistently lower than in the lighter fractions of ash from the same factory analysed previously (Pousada et al. 2003). Ca/Mg ratio (estimated from Mehlich concentrations expressed as $\mathrm{cmol} \mathrm{kg}^{-1}$ ) was 4 , within the acceptable range for soil-amendment use.

The water-soluble concentrations of the other metals ( $\mathrm{Fe}, \mathrm{Mn}, \mathrm{Mo}, \mathrm{Co}, \mathrm{Zn}, \mathrm{Cu}, \mathrm{Cd}, \mathrm{Cr}, \mathrm{Pb}$, and $\mathrm{Hg}$ ) and As were in all cases low. Mehlich-3-extractable concentrations (a measure of plant-available concentrations) were likewise low, and in all cases lower than in the fly-ash fraction of these ashes (Pousada et al. 2003). Mehlich-3-extractable concentrations (and indeed total concentrations in acid digests) were in all cases within the acceptable range of values for recycled wood ash as recommended by the Swedish Board of Forestry (Mellbo et al. 2008).

Water-soluble sulphur concentrations were high, indeed higher than total sulphur concentration in the ashes previously studied (Holmberg et al. 2000). 
Table 3. Elemental concentrations of the first wood ash and sewage sludge batch used in the present study, as determined in aqueous extracts and Mehlich 3

\begin{tabular}{|c|c|c|c|c|}
\hline \multirow{2}{*}{$\mathrm{mg} \mathrm{kg}^{-1}$} & \multicolumn{2}{|c|}{ Ash } & \multicolumn{2}{|c|}{ Sludge } \\
\hline & Water & Mehlich3 & Water & Mehlich3 \\
\hline $\mathrm{Ca} / \mathrm{Mg}$ & & 4.0 & & 6.1 \\
\hline $\mathrm{Ca}$ & 204.0 & 11898 & 388.9 & 26959 \\
\hline $\mathrm{Mg}$ & 57.42 & 1764 & 98.37 & 2668 \\
\hline $\mathrm{Na}$ & 185.7 & $*$ & 1107 & * \\
\hline K & 495.5 & 2462 & 242.4 & 1254 \\
\hline $\mathrm{Fe}$ & 0.82 & 418.3 & 2.00 & 3641 \\
\hline $\mathrm{Al}$ & 6.23 & 1732 & 4.28 & 321.0 \\
\hline Mn & 0.29 & 304.6 & 0.50 & 221.4 \\
\hline $\mathrm{Zn}$ & 0.52 & 17.57 & 4.76 & 571.9 \\
\hline $\mathrm{Ni}$ & 0.08 & 1.03 & 0.76 & 6.17 \\
\hline $\mathrm{Cu}$ & 0.58 & 6.28 & 1.32 & 5.08 \\
\hline $\mathrm{Co}$ & 0.07 & 0.44 & 0.43 & 1.17 \\
\hline $\mathrm{Cd}$ & $<0.02$ & $<0.09$ & 0.12 & 0.08 \\
\hline & $<0.06$ & 0.40 & 0.14 & 11.70 \\
\hline $\mathrm{Pb}$ & 0.02 & 7.51 & $<0.02$ & 15.59 \\
\hline S & 166.8 & 161.5 & 1873 & 2811 \\
\hline Mo & 0.45 & 0.69 & 1.98 & 0.98 \\
\hline $\mathrm{Hg}$ & $<0.50$ & $<0.50$ & $<0.07$ & $<0.07$ \\
\hline As & 0.38 & 1.39 & 1.18 & 6.92 \\
\hline B & 3.02 & $<0.02$ & $<0.02$ & $<0.02$ \\
\hline $\mathrm{P}$ & 3.25 & 1136 & 16.22 & 1857 \\
\hline
\end{tabular}

$\mathrm{Ca} / \mathrm{Mg}=\mathrm{Ca} / \mathrm{Mg}$ ratio (estimated from Mehlich concentrations expressed as $\left.\mathrm{cmol} \mathrm{kg}^{-1}\right) ;(*)=$ no data available

\section{Characteristics of the sludge}

Chemical properties of the sludge are summarized in table 2.This sludge was also alkaline and had clearly higher moisture content, electrical conductivity and total $\mathrm{N}$ concentration than the wood ash, while its carbon concentration and $\mathrm{C} / \mathrm{N}$ ratio were lower. This material has also been sampled and analysed for years, showing high variability, but its $\mathrm{N}$ concentration was always clearly higher than that of the wood ash. In view of that, and given that tree growth and biomass production is N-limited on most mineral soils (Augusto et al. 2008), it seems interesting performing and using appropriate mixtures of the sewage sludge and the wood ash here studied.

Water-soluble sulphur, sodium, calcium, potassium and magnesium concentrations were high (Table 3 ), as reflected by the high electrical conductivity. However, soluble concentrations of the remaining elements were rather low, probably because of reduced solubility due to the alkaline $\mathrm{pH}$. Mehlich3 -extractable concentrations of calcium, magnesium, potassium, aluminium, iron, manganese and chromium were all high, and higher than those reported by Wong et al. (2001) and Fuentes et al. (2004) in DTPA extracts of WTP sludge. The $\mathrm{Ca} / \mathrm{Mg}$ ratio (calculated on the basis of Mehlich-3-extractable concentrations) at 6.1 was higher than in the ash but acceptable for soil-amendment use. 


\section{Characteristics of the A-S-1 ash-sludge mixture}

The physical and chemical properties of the mixture are summarized in table 4 . The $\mathrm{pH}$ of the recently prepared mixture (7.99) was near to that of the sludge alone. After storage for one week, $\mathrm{pH}$ had increased to 8.39 , but it then declined to about 7.63 after 6 weeks of incubation. This indicates that both acidification and neutralization processes occur during storage of the mixture. In view of the nature of the individual components (Tables 2 and 3), likely explanations for the initial change include solubilisation of calcium and magnesium oxides present at high concentration in the ashes, while likely explanations for the observed longer-term acidification include mineralization of organic matter and salt formation.

Electrical conductivity remained high throughout the storage period, and was highest at the end of the period, indicating release of certain soluble ions with increasing time of contact between the two components.

Carbon concentration declined between week 0 and week 3 , confirming the existence of mineralization processes. By week 6 , however, carbon concentration had increased again, almost returning to the week- 0 value of $24 \%$. A possible explanation for this is that the most readily oxidized carbon compounds (mostly components of the sludge, but also the more labile components of the ashes) were mineralized between weeks 0 and 3; but subsequently (between weeks 3 and 6), other more recalcitrant carbon compounds were converted to more labile forms, giving rise to an increase in the measured carbon concentration. This explanation could be taken into account due to the oxidation method employed to determine $C$, but there are other possible explanations, such as that carbon has been fixed by microbial activity or by reaction of the alkaline media with atmospheric carbon dioxide.

$\mathrm{N}$ concentrations and $\mathrm{C} / \mathrm{N}$ ratios are clearly more appropriate for tree growth than that of the wood ash or sewage sludge alone (Augusto et al. 2008, Saarsalmi et al. 2006).

Table 4. Physical and chemical properties of the first ash-sludge mixture $(\mathrm{A}-\mathrm{S}-1)$, before storage $(\mathrm{t}=0)$ and after storage for 1,3 or 6 weeks.

\begin{tabular}{|lcccc|}
\hline & $\mathrm{t}=0$ & 1 week & 3 week & 6 week \\
\hline $\mathrm{pH}\left(\mathrm{in} \mathrm{H} \mathrm{H}_{2} \mathrm{O}\right)$ & 7.99 & $8.39( \pm 0.18)$ & $7.79( \pm 0.25)$ & $7.63( \pm 0.10)$ \\
$\mathrm{EC}\left(\mu \mathrm{S} \mathrm{cm}^{-1}\right)$ & 815 & $1008( \pm 52)$ & $1012( \pm 106)$ & $1339( \pm 57)$ \\
$\begin{array}{l}\text { Carbon }\left(\mathrm{g} \mathrm{kg}^{-1}\right. \\
\text { dry weight })\end{array}$ & 231 & $133( \pm 3)$ & $64.4( \pm 1.6)$ & $201( \pm 2)$ \\
$\begin{array}{l}\text { Total Kjeldahl N } \\
\left(\mathrm{g} \mathrm{kg} \mathrm{g}^{-1} \text { dry }\right. \\
\text { weight })\end{array}$ & 3.4 & $4.3( \pm 0.1)$ & $9.1( \pm 0.1)$ & $8.4( \pm 0.1)$ \\
\begin{tabular}{l}
$\mathrm{C} / \mathrm{N}$ ratio \\
\hline
\end{tabular} & 70 & $31( \pm 13)$ & $7.1( \pm 1.3)$ & $23( \pm 3)$ \\
\hline
\end{tabular}

Mehlich-3-extractable phosphorus concentration increased initially (between week 0 and week 1), but then declined.

Water-soluble calcium concentration declined between week 0 and week 1. Maximum water-soluble calcium concentration thus coincided with minimum water-soluble phosphorus concentration (reached after 6 weeks of incubation), which may indicate coprecipitation: part of the calcium released may react with phosphate, thus becoming immobilized. Water-soluble calcium (Table 5) as a percentage of total available calcium (i.e. Mehlich-3-extractable calcium; Table 6 was $7.2 \%$ at week $0,3.3 \%$ at week 1 , $9.9 \%$ at week 3 , and $13.7 \%$ at week 6 ; these fluctuations may reflect precipitation/solubilisation processes induced by $\mathrm{pH}$ fluctuations. 
Table 5. Chemical composition of the first ash-sludge mixture (A-S-1), as determined in aqueous extracts, before storage $(t=0)$ and after storage for 1,3 or 6 weeks.

\begin{tabular}{|c|c|c|c|c|}
\hline $\mathrm{mg} \mathrm{kg}^{-1}$ & $\mathrm{t}=0$ & 1 week & 3 week & 6 week \\
\hline $\mathrm{P}$ & 10.11 & $46.70( \pm 8.74)$ & $20.39( \pm 1.70)$ & $16.26( \pm 2.66)$ \\
\hline $\mathrm{Ca}$ & 642.5 & $251.3( \pm 61.5)$ & $920.6( \pm 266.6)$ & $1229( \pm 187)$ \\
\hline $\mathrm{Mg}$ & 176.5 & $62.33( \pm 1.20)$ & $237.6( \pm 4.8)$ & $321.8( \pm 3.1)$ \\
\hline $\mathrm{Na}$ & 177.5 & $195.1( \pm 14.4)$ & $188.7( \pm 9.4)$ & $216.9( \pm 5.9)$ \\
\hline $\mathrm{K}$ & 280.5 & $185.3( \pm 25.7)$ & $228.7( \pm 30.4)$ & $349.3( \pm 20.6)$ \\
\hline $\mathrm{Fe}$ & 0.64 & $0.98( \pm 0.10)$ & $0.53( \pm 0.07)$ & $0.29( \pm 0.02)$ \\
\hline $\mathrm{Al}$ & 0.85 & $2.19( \pm 0.44)$ & $3.07( \pm 6.96)$ & $0.35( \pm 0.16)$ \\
\hline $\mathrm{Mn}$ & 1.12 & $0.65( \pm 0.09)$ & $0.85( \pm 0.34)$ & $0.46( \pm 0.28)$ \\
\hline $\mathrm{Zn}$ & 1.85 & $1.68( \pm 0.30)$ & $0.87( \pm 0.15)$ & $0.91( \pm 0.19)$ \\
\hline $\mathrm{Ni}$ & 0.28 & $0.23( \pm 0.03)$ & $0.24( \pm 0.08)$ & $0.42( \pm 0.03)$ \\
\hline $\mathrm{Cu}$ & 0.63 & $0.53( \pm 0.09)$ & $0.42( \pm 0.08)$ & $0.71( \pm 0.04)$ \\
\hline Co & 0.10 & $0.09( \pm 0.02)$ & $0.08( \pm 0.02)$ & $0.10( \pm 0.01)$ \\
\hline $\mathrm{Cd}$ & 0.03 & $0.02( \pm 0)$ & $0.02( \pm 0.01)$ & $0.03( \pm 0)$ \\
\hline $\mathrm{Cr}$ & 0.04 & $0.06( \pm 0.01)$ & $0.03( \pm 0.01)$ & $0.03( \pm 0.01)$ \\
\hline $\mathrm{Pb}$ & $<0.02$ & $<0.02$ & $<0.02$ & $<0.02$ \\
\hline S & 811.7 & $747.3( \pm 161.9)$ & $1116( \pm 300)$ & $1563( \pm 199)$ \\
\hline Mo & 0.32 & $0.27( \pm 0.04)$ & $0.62( \pm 0.72)$ & $0.52( \pm 0.12)$ \\
\hline $\mathrm{Hg}$ & 0.03 & $0.01( \pm 0.02)$ & $<0.002$ & $<0.002$ \\
\hline As & 0.55 & $0.37( \pm 0.20)$ & $0.54( \pm 0.20)$ & $0.85( \pm 0.17)$ \\
\hline B & 0.77 & $0.19( \pm 0.12)$ & $0.66( \pm 0.84)$ & $0.95( \pm 0.11)$ \\
\hline
\end{tabular}

Table 6. Chemical composition of the first ash-sludge mixture (A-S-1), as determined in Mehlich 3 extracts, before storage $(t=0)$ and after storage for 1,3 or 6 weeks.

\begin{tabular}{|cclll|}
\hline $\mathrm{mg} \mathrm{kg}^{-1}$ & $\mathrm{t}=0$ & \multicolumn{1}{c}{1 week } & \multicolumn{1}{c}{3 week } & \multicolumn{1}{c|}{6 week } \\
& & & & \\
\hline $\mathrm{P}$ & 2147 & $2474( \pm 69)$ & $2364( \pm 45)$ & $1697( \pm 41)$ \\
$\mathrm{Ca}$ & 8910 & $7318( \pm 437)$ & $9310( \pm 238)$ & $8944( \pm 748)$ \\
$\mathrm{Mg}$ & 1133 & $933( \pm 48)$ & $1306( \pm 244)$ & $1411( \pm 80)$ \\
$\mathrm{K}$ & 1197 & $1204( \pm 60)$ & $1652( \pm 61)$ & $1745( \pm 111)$ \\
$\mathrm{Fe}$ & 328.9 & $499.6( \pm 43.8)$ & $359.4( \pm 28.9)$ & $262.3( \pm 13.8)$ \\
$\mathrm{Al}$ & 1087 & $1380( \pm 42)$ & $1461( \pm 129)$ & $998.5( \pm 40)$ \\
$\mathrm{Mn}$ & 135.5 & $132.4( \pm 5)$ & $149.5( \pm 17.9)$ & $128.8( \pm 11.2)$ \\
$\mathrm{Zn}$ & 124.8 & $107.6( \pm 7.4)$ & $165.1( \pm 24.4)$ & $147.7( \pm 8.6)$ \\
$\mathrm{Ni}$ & 0.95 & $1.01( \pm 0.02)$ & $1.07( \pm 0.15)$ & $1.07( \pm 0.19)$ \\
$\mathrm{Cu}$ & 10.70 & $3.14( \pm 2.09)$ & $12.50( \pm 2.66)$ & $10.04( \pm 1.69)$ \\
$\mathrm{Co}$ & 0.18 & $0.19( \pm 0.01)$ & $0.18( \pm 0.02)$ & $0.19( \pm 0.02)$ \\
$\mathrm{Cd}$ & 0.07 & $0.05( \pm 0.01)$ & $0.10( \pm 0.02)$ & $0.10( \pm 0)$ \\
$\mathrm{Cr}$ & 0.73 & $1.28( \pm 0.11)$ & $1.26( \pm 0.34)$ & $0.40( \pm 0.03)$ \\
$\mathrm{Pb}$ & 5.60 & $4.17( \pm 0.71)$ & $5.21( \pm 0.81)$ & $4.56( \pm 0.33)$ \\
$\mathrm{S}$ & 631.6 & $647.2( \pm 71.7)$ & $1108( \pm 353)$ & $1307( \pm 182)$ \\
$\mathrm{Mo}$ & 0.04 & $0.08( \pm 0.08)$ & $0.06( \pm 0.05)$ & $0.14( \pm 0.09)$ \\
$\mathrm{As}$ & 1.46 & $1.51( \pm 0.03)$ & $2.18( \pm 0.41)$ & $1.44( \pm 0.11)$ \\
\hline
\end{tabular}

Note: ( \pm Standard deviation in brackets); $\mathrm{Hg}$ and B were not detected in the Mehlich 3 extracts

Similarly, water-soluble magnesium and potassium concentrations declined between weeks 0 and 1 , but subsequently increased (Table 5). Total available concentrations of these ions showed some similar behaviour, although $\mathrm{K}$ did not decline in the first week (Table 6). This increase in the availability of bases coincides with a decline in available aluminium, iron and manganese: in other words, the availability of different cations showed different time-courses. In this connection, it should be borne in mind that wood ashes of this type have a markedly heterogeneous composition reflecting differing degrees of combustion. This is of key importance, since woody material burnt at low temperatures (around $600^{\circ} \mathrm{C}$ ) contains predominantly $\mathrm{CaCO}_{3}$ and $\mathrm{K}_{2} \mathrm{Ca}\left(\mathrm{CO}_{3}\right)_{2}$, while material burnt at $1300^{\circ} \mathrm{C}$ contains predominantly 
$\mathrm{CaO}$ and $\mathrm{MgO}$, since potassium begins to volatilize at around $800-900^{\circ} \mathrm{C}$ (Misra et al. 1993). Sulphur volatilizes at around $1000-1200^{\circ} \mathrm{C}$, and boron and copper at around $1300^{\circ} \mathrm{C}$ (Misra et al. 1993). Thus the presence of wood fragments of different sizes, reflecting different combustion temperatures, may explain the apparent fluctuations in element concentrations over the storage period.

$\mathrm{Ca} / \mathrm{Mg}$ ratio remained at around 4 - within the acceptable range for agricultural use - throughout the incubation period.

The results obtained for other minor elements were varied. Nickel, cobalt, cadmium, chromium and mercury were present in very small quantities in the mixture, both in water-soluble and Mehlich-3extractable form (Tables 5 and 6), although Mehlich-3-extractable-form concentrations were in all cases higher. Molybdenum was likewise present in very small quantities, though water-soluble concentration was slightly higher than Mehlich-3-extractable form, possibly because the acidity of the Mehlich 3 reagent increased the solubility of molybdenum salts, given that the $\mathrm{pH}$ of the mixture remained alkaline throughout the experiment (7.63 to 8.39). Zinc was present in small quantities in the watersoluble fraction, but much higher quantities in Mehlich 3 extracts; zinc concentrations in the Mehlich 3 extracts of the mixture were much lower than in the sludge alone, and much higher than in the ash alone. Copper was likewise present at smaller quantities in the aqueous extract than in the Mehlich 3 extract, and Mehlich-3-extractable copper concentration in the mixture was higher than in either the sludge or the ash alone. In general, though, most elements were present at lower soluble and available concentrations in the mixture than in either the sludge or the ashes alone, some of them were present at higher concentrations in the sludge than in the ashes or in the mixture. After the six weeks of incubation time, heavy metals, whether in soluble or available form, showed similar or lower levels than those prevailing in each of the different wastes by themselves. These differences cannot be attributed solely to $\mathrm{pH}$ variations during the experiment (which were minor), but are instead attributable to processes of adsorption/desorption, precipitation/solubilisation, or complex formation; redox processes can be assumed to have been unimportant, since the entry of oxygen was not impeded at any time in the experiment. Similar results were obtained for minor elements in a previous study of element solubilities in a soil treated with mixtures of coal ash and organic wastes (Jackson et al. 1999).

\section{E. coli levels}

E. coli-MPN is shown in table 7. E. coli levels remained low in both ash and quicklime over the 29 days of storage. By contrast, sludge $E$. coli levels remained high but with some decrease after 29 days of storage.

The Q-S-2 mixture had the lowest count of E. coli. This mixture included a higher proportion of lime (41\%) than Q-S-1 and had a pH $>12$ during the 29 days of storage (Table 8). The mixture Q-S-1, with lower percentage of lime (15\%) and, consequently, with lower $\mathrm{pH}$, showed a significant count of E. coli at the start but this dropped to low values, after 9 days of storage, and remained low in spite of the progressive $\mathrm{pH}$ reduction. It seems that the initial alkalinity impact on the microbiological count was irreversible, and the count remains low for at least 29 days even thoughpH conditions in the mediumbecome more favourable for microbial growth. 
Table 7. E. coli counts (MPN g ${ }^{-1}$ ) in wood ash, sewage sludge, in the second ash-sludge mixture (A-S-2), and in the quicklime-sludge mixtures (Q-S-1 and Q-S-2) before storage $(\mathrm{t}=0)$ and after storage for 9,14 or 29 days.

\begin{tabular}{|c|c|c|c|c|}
\hline & $\mathrm{t}=0$ & Day-9 & Day-14 & Day-29 \\
\hline Ash & $<10$ & $<10$ & $<10$ & $<10$ \\
\hline Sludge & $>999$ & $>999$ & $>999$ & $100-999$ \\
\hline Quicklime & $<10$ & $<10$ & $<10$ & $<10$ \\
\hline A-S-2 & $100-999$ & $>999$ & $100-999$ & $<10$ \\
\hline Q-S-1 & $100-999$ & $<10$ & $<10$ & $<10$ \\
\hline Q-S-2 & $<10$ & $<10$ & $<10$ & $<10$ \\
\hline
\end{tabular}

Table 8. $\mathrm{pH}$ (in $\mathrm{H} 2 \mathrm{O}$ ) in wood ash, sewage sludge, quicklime, in the second ash-sludge mixture (A-S-2) and in quicklime-sludge mixtures (Q-S-1 and Q-S-2), before storage $(\mathrm{t}=0)$ and after storage

\begin{tabular}{|l|c|c|c|}
\hline & $\mathrm{t}=0$ & Day-9 & Day-29 \\
\hline Ash & 9.82 & 9.69 & 9.55 \\
\hline Sludge & 8.38 & 8.25 & 8.33 \\
\hline Quicklime & 12.80 & 12.71 & 12.67 \\
\hline A-S-2 & 8.51 & 8.25 & 7.53 \\
\hline Q-S-1 & 11.45 & 11.10 & 8.21 \\
\hline Q-S-2 & 12.75 & 12.77 & 12.63 \\
\hline
\end{tabular}

Initially, the E. coli counts were similar for the quicklime-sludge mixture Q-S-1 and the ash-sludge mixture A-S-2, but after nine days E. coli counts clearly increased for the latter, showing that $\mathrm{pH}$ values between 8.45 and 8.25 could not avoid bacterial growth in this ash-sludge mixture. However, the $E$. coli count decreased for A-S-2 at day 29, even with lower $\mathrm{pH}$ (7.53).The results indicate that mixing ash with sludge does not givequick reductions of $E$. coli. If quick reduction is a priority, more alkaline materials such as quicklime in addition to wood ash need to be added to the sludge.

\section{CONCLUSIONS}

Mixtures of $70 \%$ wood ash and 30\% sewage sludge (A-S-1) have element concentrations within acceptable limits for agricultural and forestry use, both immediately after mixing and after storage for up to 6 weeks.

The mixture had higher plant-available $\mathrm{Ca}, \mathrm{Mg}$ and $\mathrm{K}$ concentrations than either component alone, with no increase in heavy metal availability. Element availabilities changed over 6 weeks' storage of the mixture: available calcium, magnesium and potassium concentrations increased. Carbon concentration showed marked fluctuations and eventually dropped below the starting level. 
Dissolution during storage of oxides and carbonates from the ashes - together with mineralization of part of the organic matter present in the sludge, and possibly organic matter remaining in the ashes - gave rise to a mixture with properties apparently well-suited to acid or degraded soils, in view of its high base content and low heavy metal levels. Mixtures of this type would be suitable to enhance wood ash and sewage sludge recycling, contributing to reduce cost and to solve waste management problems while increasing soil productivity.

The study of $E$. coli survival during the storage showed lowest survival in the quicklime-sludge mixture (Q-S-2) which had a $\mathrm{pH}>12$. The ash-sludge mixture(A-S-2) used for microbiological test did not show quick reduction of E. coli counts. So, if bacterial reduction is a priority, aging for at least 29 days or addition ofquicklime to the sewage sludge and wood ash mixture is necessary.

\section{ACKNOWLEDGEMENTS}

We thank the support of Xunta de Galicia's I+D Plan (R+D Plan, Government of Galicia, Spain), and the private companies Tablicia, S.A. and CEDIE, S.A.

\section{REFERENCES}

Abbott, D.E.; Essington, M.E.; Mullen, M.D.; Ammons, J.T. 2001. Fly ash and lime-stabilized biosolid mixtures in mine spoil reclamation: simulated weathering. J. Environ. Qual 30 (2): 608-616.

Augusto, L.; Bakker, M.R.; Meredieu, C. 2008. Wood ash applications to temperate forest ecosystems -potential benefits and drawbacks. Plant Soil 306 (1-2): 181-198.

Canet, R.; Pomares, F.; Tarazona, F.; Estela, M. 1998. Sequential fractionation and plant availability of heavy metals as affected by sewage sludge application to soil. Communications in Soil Science and Plant Analysis 29 (5-6): 697-716.

Demeyer, A.; Voundi Nkana, J.C.; Verloo, M.G. 2001. Characteristics of wood ash and influence on soil properties and nutrient uptake: an overview. Biores. Technol. 77: 287-295.

Dimitriou, I.; Eriksson, J.; Adler, A.; Aronsson, P.; Verwijst, T. 2006. Fate of heavy metals after application of sewage sludge and wood-ash mixtures to short-rotation willow coppice. Environ. Pollution 142 (1): 160-169.

Fuentes, A.; LLoréns, M.; Sáez, J.; Soler, A.; Aguilar, M.I.; Ortuño, J.F.; Meseguer, V.F. 2004. Simple and sequential extractions of heavy metals from different sewage sludges. Chemosphere 54 (8): 1039-1047.

Guitián, F.; Carballas, T. 1976. Técnicas de análisis de suelos. Pico Sacro, Santiago de Compostela. España. 288 pp.

Holmberg, S.L.; Lind, B.B.; Claesson, T. 2000. Chemical composition and leaching characteristics of granules made of wood ash and dolomite. Environ. Geol. 40 (1-2): 1-10.

Holmström, S.J.M.; Riise, G.; Strand, L.T.; Geibe, C.; Van Hees, P.A.W.; Wu, Q.; Lundström, U.S. 2003. Effects of lime and ash treatments on DOC fractions and low molecular weight organic acids in soil solutions of acidified podzolic soils. Water, Air \& Soil Pollution: Focus 3: 97-120. 
Hospido, A.; Moreira, M.T.; Fernández-Couto, M.; Feijoo, G. 2007. Environmental performance of a municipal wastewater treatment plant. Int. J. Life Cycle Ass. 9(4): 261-271.

Jackson, B.P.; Miller, W.P.; Schumann, A.W.; Sumner, M.E. 1999. Trace element solubility from land application of fly ash/organic waste mixtures. J. Environ. Qual. 28 (2): 639-647.

Lundström, U.S.; Bain, D.C.; Taylor, A.F.S.; Van Hees, P.A.W. 2003. Effects of acidification and its mitigation with lime and wood ash on forest soil processes: a review. Water, Air \& Soil Pollution: Focus 3 (4): 5-28.

Mehlich, A. 1984. Mehlich 3 soil test extractant. A modification of Mehlich 2 extractant. Communications in Soil Science and Plant Analysis 15 (2): 1409-1416.

Mellbo, P.; Sarenbo, S.; Stalnacke, O.; Claesson, T. 2008. Leaching of wood ash products aimed for spreading in forest floors- Influence of method and L/S ratio. Waste Manage 28 (11): 2235-2244.

Misra, M.K.; Ragland, K.W.; Baker, A.J. 1993. Wood ash composition as a function of furnace temperature. Biomasa and Bioenerg. 4 (2): 103-116.

Pousada, M.Y.; Núñez, A.; Seoane, S. 2003. Evaluación de la mezcla de lodos residuales con cenizas de combustión de madereras como enmienda de suelos ácidos, in: Bienes, R., Marqués, M.J. (Eds.), I Simposio Nacional sobre Control de la Erosión y Degradación del Suelo, Madrid, España, (9-11 de Julio). 299-302.

Pousada, M.Y.; Núñez, A.; Seoane, S. 2005a. Changes throughout storage, in the physico-chemical characteristics of a mixture containing wood ash, sewage sludge and meat flour. in: Bernal, P., Moral, R., Clemente, R., Paredes, C. (Eds.), Sustainable organic waste management for environmental protection and food safety Vol. 2, FAO-CSIC. Murcia, España. 215-218.

Pousada, M.Y.; Núñez, A.; Seoane, S. 2005b. Evaluation of a mixture of wood ash, sewage sludge and meat flour, in: Bernal, P., Moral, R., Clemente, R., Paredes, C. (Eds.), Sustainable organic waste management for environmental protection and food safety Vol. 2, FAO-CSIC. Murcia, España. 219222.

Reimann, C.; Ottesen, R.T.; Andersson, M.; Arnoldussen, A.; Koller, F.; Englmaier, P. 2008. Element levels in birch and spruce wood ashes - green energy? Sci. Total Environ. 393 (2-3): 191197.

Saarsalmi, A.; Kukkola, M.; Moilanen, M.; Arola, M. 2006. Long-term effects of ash and N fertilization on stand growth, tree nutrient status and soil chemistry in Scots pine stand. Forest Ecology and Management 235 (1-3): 116-128.

Schumann, A.W.; Sumner, M.E. 2000. Chemical evaluation of nutrient supply from fly ash-biosolids mixtures. Soil. Sci. America J. 64 (1): 419-426.

Solla-Gullón, F.; Santalla, M.; Pérez-Cruzado, C.; Merino, A.; Rodríguez-Soalleiro, R. 2008. Response of Pinus radiata seedlings to application of mixed wood-bark ash at planting in a temperate region: Nutrition and growth. For. Ecol. Manage 255 (11): 3873-3884. 
Sueiro, P. 2010. Inertización y promoción del reciclado de restos pastosos de fuel mediante mezclado con encalantes, cenizas y lodos. Ph. D. Thesis, Univ. Santiago de Compostela. Santiago de Compostela, España. 876 pp.

Sumner, M.E. 2000. Beneficial use of effluents, wastes, and biosolids. Communications in Soil Science and Plant Analysis 31 (11-14): 1701-1715.

Tan, K.H. 1996. Soil Sampling, Preparation and Analysis. Marcel Deker, New York.USA. 408 pp.

Van Hees, P.A.W.; Nyberg, L.; Holmström, S.J.M.; Lundström, U.S. 2003. Pools and fluxes of cations, anions and DOC in two forest soils treated with lime and ash. Water, Air, \& Soil Poll: Focus 3 (4): 145-165.

Vance, E.D. 1996. Land application of wood-fired and combination boiler ash: an overview. $J$. Environ. Qual. 25 (5): 937-944.

Wong, J.W.C.; Lai, K.M.; Su, D.S.; Fang, M. 2001. Availability of heavy metals for Brassica chinensis grown in acidic loamy soil amended with a domestic and industrial sewage sludge. Water, Air, \& Soil Pollution: Focus 128 (3-4): 339-353. 